Spring 2017

\title{
Second-Tier Certiorari: Adverse Precedential Effect as a Predicate for Finding a "Miscarriage of Justice" in Government Appeals
}

John A. Greco

City of Miami

Follow this and additional works at: https://ecollections.law.fiu.edu/lawreview

Part of the Courts Commons, and the State and Local Government Law Commons

Online ISSN: 2643-7759

\section{Recommended Citation}

John A. Greco, Second-Tier Certiorari: Adverse Precedential Effect as a Predicate for Finding a "Miscarriage of Justice" in Government Appeals, 12 FIU L. Rev. 297 (2017).

DOI: https://dx.doi.org/10.25148/lawrev.12.2.6

This Article is brought to you for free and open access by eCollections. It has been accepted for inclusion in FIU Law Review by an authorized editor of eCollections. For more information, please contact lisdavis@fiu.edu. 


\section{SECOND-TiER CERTIORARI: AdVERSE PrECEDENTIAL EFFECT AS A \\ PREDICATE FOR FINDING A "MISCARRIAGE OF JUSTICE" IN \\ GOVERNMENT APPEALS}

John A. Greco, Esq.*

\section{INTRODUCTION}

Quasi-judicial decisions of local governments are appealable as a matter of right to the circuit courts. ${ }^{1}$ The types of government decisions subject to appeal to the circuit court usually include orders of code enforcement boards, personnel boards, and municipal legislative bodies acting in a quasi-judicial capacity. The subject matter of the decisions include compliance with building requirements, employment actions, and land use and zoning determinations.

The certiorari jurisdiction of the district courts of appeal may be sought to review the circuit court's appellate decision. This review is customarily referred to as "second-tier certiorari." Among other requirements for second-tier certiorari, the district court of appeal is only authorized to issue the writ to the circuit court upon a determination that the decision results in a "miscarriage of justice." The Florida Supreme Court has equated a miscarriage of justice in this context with error that is so serious that justice requires that it be corrected. ${ }^{2}$ Further, the "miscarriage of justice" standard for second-tier certiorari contains a degree of flexibility and discretion and is generally determined on a case-by-case basis. ${ }^{3}$

There are instances where the district courts of appeal grant second-tier certiorari finding a miscarriage of justice - not necessarily because of the effect on the petitioner, but because of the precedential impact of the decision on other cases. Some courts have also factored the public interest into the analysis. This article examines the application of the miscarriage of justice standard based upon the precedential effect of the circuit court's appellate decision, and in particular where the public interest is at stake. First, the article briefly introduces second-tier certiorari. Second, the article sets forth the miscarriage of justice standard as articulated by the Florida

\footnotetext{
* John A. Greco. Deputy City Attorney and Chief Appellate Counsel for the City of Miami. He practices in the areas of appellate, constitutional, governmental, administrative, labor, and employment law.

Art. V, $\S 5(b), 20(c)(3)$, Fla. Const.

2 Combs v. State, 436 So. 2d 93 (Fla. 1993); Haines City Cmty. Dev. v. Heggs, 658 So. 2 d 523 (Fla. 1995).

3 Combs, 436 So. 2 d at 93; Heggs, 658 So. 2 d at 523.
} 
Supreme Court. Finally, the article analyzes authority from the district courts of appeal applying the miscarriage of justice standard based on the adverse precedential effect of the circuit court appellate decision and the public interest.

\section{ApPeals of Local GoVernment Decisions FIRST-TIER REVIEW}

Local government decisions, quasi-judicial in nature, are appealable, as a matter of right, to the circuit court. ${ }^{4}$ In City of Deerfield Beach v. Vaillant, the Florida Supreme Court elucidated the framework for the circuit court's review of local government decisions:

Where a party is entitled as a matter of right to seek review in the circuit court from administrative action, the circuit court must determine whether procedural due process is accorded, whether the essential requirements of the law have been observed, and whether the administrative findings and judgment are supported by competent substantial evidence. ${ }^{5}$

Thus, on this "first-tier" review, the circuit court reviews the local government decision to determine whether it is supported by competent substantial evidence, complies with the essential requirements of the law, and affords due process.

\section{SECOND-TIER REVIEW}

The district courts of appeal are authorized under their certiorari jurisdiction to review decisions of the circuit courts acting in their appellate capacity. ${ }^{6}$ This "second-tier" review, however, does not afford the parties a second appeal. ${ }^{7}$ As stated by the Florida Supreme Court, review becomes

4 Art. V, $\S \S 5($ b), 20(c)(3), Fla. Const.; Broward Cty. v. G.B.V. Int'l, Ltd., 787 So. 2d 838, 843 (Fla. 2001) ("In brief, first-tier certiorari review is not discretionary but rather is a matter of right and is akin in many respects to a plenary appeal, whereas second-tier certiorari review is more restricted and is similar in scope to true common law certiorari.").

5 City of Deerfield Beach v. Vaillant, 419 So. 2d 624, 626 (Fla. 1982).

6 See Art. V, § 4(b)(3), Fla. Const. (providing certiorari jurisdiction of the district courts of appeal); see also Fla. R. App. P. 9.030(b)(2)(B) (certiorari jurisdiction of district courts of appeal includes review of final orders of circuit courts acting in their review capacity).

7 Custer Medical Ctr. v. United Auto. Ins. Co., 62 So. 3d 1086, 1093 (Fla. 2010) ("In other words, this Court has definitively expressed that certiorari cannot be used to grant a second appeal to correct the existence of mere legal error.... This is necessary because, unlike an appeal, common-law certiorari is an entirely discretionary exercise of jurisdiction by the court and is not taken as a matter of right."). 
narrower as it proceeds up the judicial ladder. ${ }^{8}$

The Florida Supreme Court has described second-tier review as follows:

We hold that where full review of administrative action is given in the circuit court as a matter of right, one appealing the circuit court's judgment is not entitled to a second full review in the district court. Where a party is entitled as a matter of right to seek review in the circuit court from administrative action, the circuit court must determine whether procedural due process is accorded, whether the essential requirements of the law have been observed, and whether the administrative findings and judgment are supported by competent substantial evidence. The district court, upon review of the circuit court's judgment, then determines whether the circuit court afforded procedural due process and applied the correct law. ${ }^{9}$

Hence, in order to issue a writ of certiorari quashing a decision of the circuit court acting in its appellate capacity, the district court of appeal must determine that the circuit court applied the incorrect law or denied due process. Further, as discussed in detail below, the writ of certiorari may not be issued unless the decision will result in a "miscarriage of justice."

\section{THE “MiSCARRIAGE OF JUSTICE" REQUIREMENT OF SECOND-TIER CERTIORARI REVIEW}

In addition to demonstrating failure to apply the correct law, for a court of appeal to issue the writ of certiorari in a second-tier proceeding, the failure to apply the correct law must also result in a "miscarriage of justice." In Combs v. State ${ }^{10}$ the Florida Supreme Court explained:

In granting writs of common-law certiorari, the district courts of appeal should not be as concerned with the mere existence of legal error as much as with the seriousness of the error. Since it is impossible to list all possible legal errors serious enough to constitute a departure from the essential requirements of law, the district courts must be allowed a large degree of discretion so that they may judge each case individually. The district courts should exercise

8 Vaillant, 419 So. 2 d at 626 ("As a case moves up the appellate ladder, each level of review does not become broader.").

9 Id.

10 Combs v. State, 436 So. 2d 93, 93 (Fla. 1993). 
this discretion only when there has been a violation of a clearly established principle of law resulting in a miscarriage of justice.

It is this discretion which is the essential distinction between review by appeal and review by common-law certiorari. A district court may refuse to grant a petition for common-law certiorari even though there may have been a departure from the essential requirements of the law. The district court should use this discretion cautiously so as to avert the possibility of common-law certiorari being used as a vehicle to obtain a second appeal. ${ }^{11}$

Later, the Florida Supreme Court elaborated that the standard of second-tier certiorari

while narrow, also contains a degree of flexibility and discretion. For example, a reviewing court is drawing new lines and setting judicial policy as it individually determines those errors sufficiently egregious or fundamental to merit the extra review and safeguard provided by certiorari. This may not always be easy since the errors in question must be viewed in the context of the individual case. It may also be true that review of administrative decisions may be more difficult, since care must be exercised to determine the nature of the administrative proceeding under review, and to distinguish between quasi-judicial proceedings and those legislative in nature. There is no complete catalog that the court can turn to in resolving a particular case. ${ }^{12}$

\section{AdVERSe Precedential EfFect as a BaSis FOR Finding A "MisCARRIAGE OF JUSTICE"}

Based on the above framework for second-tier certiorari, the constraints on review prevent issuance of the writ to correct simple legal error. ${ }^{13}$ As stated by the Florida Supreme Court, the purpose of the writ on second-tier certiorari is not to afford a party a "second appeal." 14

11 Id. at $95-96$.

12 Haines City Cmty. Dev. v. Heggs, 658 So. 2d 523, 530-31 (Fla. 1995) (footnote omitted).

13 See Ivey v. Allstate Ins. Co., 774 So. 2d 679 (Fla. 2000); Combs, 436 So. 2d at 93.

14 Custer Medical Ctr. v. United Auto. Ins. Co., 62 So. 3d 1086, 1093 (Fla. 2010) ("In other words, this Court has definitively expressed that certiorari cannot be used to grant a second appeal to 


\section{LIMITED REVIEW OF CIRCUIT COURT APPEALS}

Aside from this extraordinary writ, there is no mechanism for a direct judicial review by the district courts of appeal over decisions of the circuit court acting in its appellate capacity.

The Second District Court of Appeal discussed the lack of a mechanism to establish principles of law on cases that are appealed to the circuit court in Stilson v. Allstate Insurance Co. ${ }^{15}$ There, the Second District Court of Appeal considered a petition for writ of certiorari to review an affirmance of a summary judgment by the county court in a personal injury protection coverage claim. In denying the petition, the Second District Court of Appeal determined that the circuit court and the county court may have misapplied the law, but the failure to extend existing precedent to the facts in that case did not violate a clearly established principle of law. The Second District Court of Appeal further stated:

This case highlights a significant problem within our existing judicial structure. It is difficult for the law to evolve in unreported decisions issued in circuit court appeals. What evolution occurs may take conflicting approaches within the numerous circuits. As a result, there may never be "clearly established principles of law" governing a wide array of county court issues, including PIP issues.

There is a great temptation in a case like this one to announce a "miscarriage of justice" simply to provide precedent where precedent is needed. We do not interpret Heggs as giving this court that degree of discretion in a certiorari proceeding. Such an interpretation would invite certiorari review of a large number of the appellate decisions issued by circuit courts. ${ }^{16}$

correct the existence of mere legal error.... This is necessary because, unlike an appeal, common-law certiorari is an entirely discretionary exercise of jurisdiction by the court and is not taken as a matter of right.").

15 Stilson v. Allstate Ins. Co., 692 So. 2d 979 (Fla. 2d DCA 1997).

16 Id. at $982-83$. 


\section{Adverse Precedential Impact and the Public INTEREST}

In Stilson, the Second District Court of Appeal resisted the "temptation" $" 17$ to find a miscarriage of justice to fill a vacuum of precedent. ${ }^{18}$ Later that year, however, in Department of Highway Safety \& Motor Vehicles v. Alliston, ${ }^{19}$ the Second District Court of Appeal confronted a situation where the circuit court acting in its appellate capacity departed from the essential requirements of the law by requiring a more stringent standard of proof for license suspension based on DUI than mandated by statute. The Second District Court of Appeal, after finding a departure from the essential requirements of the law, discussed the difficulty in application of the "miscarriage of justice" standard:

Although we conclude that the circuit court applied the incorrect law in its review of this administrative order, this does not necessarily allow us to grant certiorari in this second-tier proceeding. The more difficult question in this case is whether the circuit court's error rises to the level that can be corrected as a "miscarriage of justice." Despite all of the efforts of the supreme court and the district courts, the test to determine when a "miscarriage of justice" has occurred remains easier to state than to apply. In measuring the seriousness of an error to determine whether second-tier certiorari is available, one consideration is whether the error is isolated in its effect or whether it is pervasive or widespread in its application to numerous other proceedings. See, e.g., Progressive Specialty Ins. Co. v. Biomechanical Trauma Ass'n, 785 So. 2d 667 (Fla. 2d DCA 2001); Stilson v. Allstate Ins. Co., 692 So. 2d 979 (Fla. 2d DCA 1997). Thus, a circuit court order that is particularly fact-specific and fact-dependent, or an order that provides a result without a written opinion and therefore cannot act as precedent in future cases, will generally not merit certiorari review in the district court, even if the district court might disagree with the result. See,

17 Id. ("There is a great temptation in a case like this one to announce a 'miscarriage of justice' simply to provide precedent where precedent is needed.").

18 See also Clark v. State, 170 So. 3d 69, 71-72 (Fla. 5th DCA 2015) (denying petition for second-tier certiorari; noting that there was a "great temptation" to "provide precedent where precedent is needed" but the solution was not through a second-tier certiorari proceeding).

19 Dep't of Highway Safety \& Motor Vehicles v. Alliston, 813 So. 2d 141 (Fla. 2d DCA 2002). 
e.g., Stilson, 692 So. $2 \mathrm{~d}$ at 982 n. $3 .^{20}$

After reviewing the standard, the Second District Court of Appeal concluded that "the circuit court's error results in a miscarriage of justice requiring certiorari relief because it has precedential value and the circuit court is applying the same error to numerous other administrative proceedings involving the suspension of driver's licenses." The Second District Court of Appeal explained:

The circuit court's order places a virtually impossible burden of proof on the DHSMV in attempting to suspend a person's license for a DUI arrest. As applied to future proceedings, the circuit court's order would seemingly require the DHSMV to present affirmative evidence, in the form of testimony from inspectors and persons who administer breath tests, that each applicable inspection and breath test complied with every protocol set forth in the administrative rules. This is not what the law requires. ${ }^{21}$

Other district courts of appeal decisions have adopted this basis for finding a miscarriage of justice, focusing however, not only on the adverse precedential effect of the decision, but also on considerations of the public interest, i.e. public safety and the burden on the government's resources. In State, Department of Highway Safety \& Motor Vehicles v. Fernandez, ${ }^{22}$ the Third District Court of Appeal found a miscarriage of justice based on adverse precedential effect, but in reaching its decision, it also relied upon the significant public interest of the Department of Highway Safety and Motor Vehicles "in regulating a citizen's driving privilege... and in keeping the public safe from persons that choose to operate vehicles while using intoxicants. ${ }^{23}$ The Third District Court of Appeal further stated the circuit court's decision would "impose a heavy burden on the Department's limited resources." 24

In Department of Highway Safety \& Motor Vehicles v. Hirtzel, ${ }^{25}$ the First District Court of Appeal followed the Third District Court of Appeal's opinion in Fernandez, finding a miscarriage of justice and granting a writ of second-tier certiorari. After quoting the opinion in Fernandez, the First District Court of Appeal stated: "Here, too, in the interests of public safety, we are constrained to adhere to the precedent we have laid down in cases

$20 \quad I d$. at 145.

21 Id. at 145-46 (footnote omitted).

22 State, Dep't of Highway Safety \& Motor Vehicles v. Fernandez, 114 So. 3d 266 (Fla. 3d DCA 2013).

$23 \quad I d$. at 272.

24 Id.

25 Dep't of Highway Safety \& Motor Vehicles v. Hirtzel, 163 So. 3d 527 (Fla. 1st DCA 2015). 
like this one." ${ }^{26}$

In State, Department of Highway Safety \& Motor Vehicles $v$. Wiggins, ${ }^{27}$ the First District Court of Appeal granted the petition for writ of certiorari in a second-tier proceeding involving a license suspension. In finding a miscarriage of justice, the First District Court of Appeal stated:

And although this case involves only Mr. Wiggins's suspension, the Department says that many similar cases currently exist; and if the circuit court's method of review is permitted, that the proverbial floodgates will open by giving the green light to circuit courts to independently review and second-guess the evidentiary weight to be placed on video evidence. Under these circumstances, where no relief is otherwise available to the Department to curtail this practice, the context of this case warrants relief. $^{28}$

Many other district court of appeal decisions addressing adverse precedential effect and the public interest involve the Department of Highway Safety and Motor Vehicles. ${ }^{29}$ However, the district courts of appeal have considered these grounds for finding miscarriage of justice in other governmental ${ }^{30}$ and non-governmental contexts. ${ }^{31}$

$26 \quad$ Id. at 531.

27 State, Dep't of Highway Safety \& Motor Vehicles v. Wiggins, 151 So. 3d 457 (Fla. 1st DCA 2014), review granted, 168 So. 3d 231 (Fla. 2014).

28 Id. at 470.

29 See, e.g., Dep't of Highway Safety \& Motor Vehicles v. Hofer, 5 So. 3d 766, 772 (Fla. 2d DCA 2009) (noting that "Appellate courts, however, have found a miscarriage of justice and exercised their certiorari jurisdiction when a decision applies incorrect law and establishes principles of general application binding in subsequent cases.”); Dep't of Highway Safety \& Motor Vehicles v. Icaza, 37 So. 3d 309 (Fla. 5th DCA 2010) (granting second-tier petition for writ of certiorari; citing to Hofer and Lorenzo for proposition that writ may be issued based upon precedential value and effect on other proceedings); Dep 't of Highway Safety \& Motor Vehicles v. Falcone, 983 So. 2d 755, 759 (Fla. 2d DCA 2008) ("As this court did in Alliston, 813 So. $2 d$ at 145 , we conclude that the circuit court's error resulted in a miscarriage of justice requiring certiorari relief because it has precedential value and the circuit court is applying the same error to numerous other administrative proceedings involving the suspension of driver's licenses."); State Dep't of Highway Safety v. Edgell-Gallowhur, 114 So. 3d 1081, 1088 (Fla. 3d DCA 2013) ("The circuit court's error established an incorrect legal principle that is binding precedent on all county court judges within the Eleventh Judicial Circuit . . . and is capable of repetition in future formal hearings, thereby continuing to deprive the Department of its ability to sustain a driver's license suspension based upon evidence which is properly admitted under the existing statutes and administrative regulations.").

30 See Maple Manor, Inc. v. City of Sarasota, 813 So. 2d 204, 207 (Fla. 2d DCA 2002) ("Because the circuit court's error has the potential to be applied to future administrative nuisance abatement proceedings, we further conclude that the circuit court's error resulted in a miscarriage of justice.").

31 See State Farm Fla. Ins. Co. v. Lorenzo, 969 So. 2d 393, 398 (Fla. 5th DCA 2007) (granting second-tier certiorari and indicating that "the error could have a pervasive, widespread effect in other proceedings.”); GEICO Indem. Co. v. Gables Ins. Recovery, Inc., 159 So. 3d 151, 155-56 (Fla. 3d DCA 


\section{AdVERSE PRECEDENTIAL EFFECT AS AN "INDEPENDENT" BASIS FOR FINDING A "MISCARRIAGE OF JUSTICE"}

Two cases from the Second District Court of Appeal demonstrate that court's consideration of adverse precedential effect separate and apart from whether or not the actual parties to the action have suffered the miscarriage of justice in that particular case. The cases are Progressive Specialty Insurance Co. v. Biomechanical Trauma Association, Inc., ${ }^{32}$ and Gould v. State. ${ }^{33}$

In Progressive Specialty Insurance Co., the county court erroneously granted summary judgment to Biomedical Trauma Association, Inc., ("Biomedical") resulting in a final judgment for \$131.09. Progressive Specialty Insurance Company petitioned for second-tier certiorari, which was granted by the Second District Court of Appeal. Thereafter, the circuit court in a different case recognized its error and receded from the case in a subsequent appeal. Biomedical then moved for rehearing. The Second District Court of Appeal granted rehearing finding that there was no longer a miscarriage of justice:

As an isolated error, the circuit court's affirmance in this case cannot be characterized as a miscarriage of justice. Given that the circuit court has already receded from its opinion in this case, it will have no adverse precedential affect upon future cases. Although the legal analysis in our opinion, which has already been published... appears correct, we withdraw that opinion. ${ }^{34}$

Thus, although the Progressive Specialty Insurance Company's position was legally correct, the court withdrew the relief when the basis for the finding of miscarriage of justice no longer existed because the circuit court eliminated the adverse precedential effect in a subsequent decision.

In Gould, the Second District Court of Appeal considered a second-tier petition for writ of certiorari to review a first-tier habeas corpus petition filed in circuit court. The Second District Court of Appeal granted the petition, finding a miscarriage of justice, even though the petitioner was released from jail. Regarding mootness due to the release from jail, the Second District Court of Appeal stated:

\footnotetext{
2014) ("Because the Appellate Division's ruling will potentially affect large numbers of claimants and large numbers of PIP claims processed by insurers, the error results in a miscarriage of justice.”).

32 Progressive Specialty Ins. Co. v. Biomechanical Trauma Ass'n, Inc., 785 So. 2d 667, 668 (Fla. 2d DCA 2001).

33 Gould v. State, 974 So. 2d 441, 442, 446 (Fla. 2d DCA 2007).

34 Progressive Specialty Ins. Co., 785 So. $2 \mathrm{~d}$ at 668.
} 
As a preliminary matter, the State asserts that Mr. Gould's release from jail renders his petition for certiorari moot. "However, mootness does not destroy a court's jurisdiction if the question raised is of great public importance or is likely to recur, or if the error is capable of repetition yet evading review." Kelley v. Rice, 800 So. 2d 247, 250 (Fla. 2d DCA 2001) (citations omitted). Mr. Gould claims that "first appearance judges in the Tenth Judicial Circuit routinely accept unsworn, conclusory uniform traffic citations from arresting officers to justify the arrest and continued detention of [DUI suspects]." The State does not dispute this assertion. Because this petition presents a question capable of repetition yet evading review, this court has jurisdiction to hear the merits even if the petition is moot. See Enter. Leasing Co. v. Jones, 789 So. 2d 964, 965 (Fla. 2001) (holding that the court may retain jurisdiction despite mootness because the issue on appeal is likely to recur). ${ }^{35}$

Regarding miscarriage of justice, the Second District Court of Appeal stated:

Although we conclude that the circuit court applied incorrect law when reviewing Mr. Gould's petition, this court cannot grant certiorari absent a showing that this departure from the essential requirements of the law constituted a "miscarriage of justice." When determining whether the circuit court's error amounts to a "miscarriage of justice," an important factor is the effect of the error on other cases. Alliston, 813 So. $2 \mathrm{~d}$ at 145 . A circuit court's decision that is particularly fact-dependent or fact-specific or that lacks precedential value because it was issued without a written opinion will generally not merit certiorari review. $I d$. However, a decision that establishes a principle of general application binding on lower courts results in a miscarriage of justice that warrants the exercise of this court's certiorari jurisdiction. See id. at 145-46.

The order denying Mr. Gould's petition establishes the general principle that a uniform traffic citation, by itself, provides probable cause for a defendant's arrest and continued detention. Furthermore, the circuit court 
appellate decision in this case is binding on all three county courts within the Tenth Judicial Circuit. See Fieselman $v$. State, 566 So. 2d 768, 770 (Fla. 1990). Because the circuit court's application of incorrect law established a legal principle binding on lower courts that is neither factdependent nor fact-specific, the circuit court's decision results in a miscarriage of justice that warrants the exercise of this court's certiorari jurisdiction. ${ }^{36}$

Thus, even though the petitioner's claim was moot, the Second District Court of Appeal found a miscarriage of justice where it determined that there would be an adverse precedential effect.

\section{THE FUTURe OF Finding MiscarRiage OF JUSTICE BASED ON ADVERSE PRECEDENTIAL EFFECT}

The Florida Supreme Court has not yet directly upheld adverse precedential effect as a basis for finding a miscarriage of justice. However, in Futch v. Florida Department of Highway Safety \& Motor Vehicles, ${ }^{37}$ a dissent by Justice Canady referenced the doctrine:

The circuit court's error also resulted in a miscarriage of justice because it has precedential value in the Seventh Judicial Circuit, could affect many other administrative proceedings in that circuit, and substantially deprives DHSMV of its opportunity to sustain driver license suspensions in that circuit. ${ }^{38}$

\section{CONCLUSION}

The miscarriage of justice requirement of issuing a second-tier writ of certiorari remains a difficult standard to apply in practice in part due to the

36 Id. at 446-47. However, the Second District Court of Appeal in Department of Highway Safety \& Motor Vehicles v. Robinson, 93 So. 3d 1090, 1091-94 (Fla. 2d DCA 2012), found no departure from the essential requirements of the law in a case involving inconsistent decisions from different circuits. On denial of review, a concurring opinion by Justice Pariente stated: "In this case, the Second District apparently did not believe that the inconsistent results within its district, where one circuit court concluded that there was a due process violation in suspending a driver's license when the arresting officer did not appear and where another circuit court made the opposite conclusion, reached the high threshold required to grant second-tier certiorari review. This may have been especially true in the particular case before it, where the circuit court actually found a due process violation and did not uphold the license suspension." Dep't of Highway Safety \& Motor Vehicles v. Robinson, 112 So. 3d 83, 85 (Fla. 2013).

37 Futch v. Dep't of Highway Safety \& Motor Vehicles, 189 So. 3d 131 (Fla. 2016).

38 Id. at $133-34$. 
fact that its application is considered on a case-by-case basis and therefore precedent does not provide useful guidance on the determination of what constitutes a miscarriage of justice. At the same time, often, the district courts of appeal, in considering a petition for writ of certiorari to review a decision of the circuit court acting in its appellate capacity, are confronted with issues of significant public importance that may have an adverse precedential effect. In this context, the district courts of appeal have adopted an approach that permits the finding of a miscarriage of justice based upon adverse precedential effect of the circuit court appellate decision without regard to whether the parties to the action suffered a miscarriage of justice in that case. The district courts of appeal have also considered the public interest and the burden on the government agency in protecting that interest. Hence, the writ has been used in the absence of the ability of district courts of appeal to address and correct errors that are in need of resolution by a further level of judicial review. Where an appellate decision of the circuit court would have an adverse precedential effect and hamper the government agency's ability to protect the public interest, local governments petitioning for a second-tier writ of certiorari would be well advised to consider this basis for demonstrating a "miscarriage of justice." 